\title{
Report: Abstracts from the 71st Caddo Conference held at University of Central Arkansas
}

Duncan P. McKinnon

University of Central Arkansas

Follow this and additional works at: https://scholarworks.sfasu.edu/ita

Part of the American Material Culture Commons, Archaeological Anthropology Commons, Environmental Studies Commons, Other American Studies Commons, Other Arts and Humanities Commons, Other History of Art, Architecture, and Archaeology Commons, and the United States History Commons

Tell us how this article helped you.

This Article is brought to you for free and open access by the Center for Regional Heritage Research at SFA ScholarWorks. It has been accepted for inclusion in Index of Texas Archaeology: Open Access Gray Literature from the Lone Star State by an authorized editor of SFA ScholarWorks. For more information, please contact cdsscholarworks@sfasu.edu. 


\section{Report: Abstracts from the 71st Caddo Conference held at University of Central}

Arkansas

\section{Creative Commons License}

\section{(c) (1) (9)}

This work is licensed under a Creative Commons Attribution-NonCommercial 4.0 International License 


\title{
Report:
}

\section{Abstracts from the 71st Caddo Conference held at University of Central Arkansas}

\author{
Duncan P. McKinnon \\ University of Central Arkansas
}

The 61st Caddo Conference was held on March 21-23, 2019 in the McCastlain Hall Ballroom on the campus of UCA. The Caddo Conference coincided with Arkansas Archeology Month. Funding was provided by UCA Foundation, the Department of Sociology, Criminology, and Anthropology (SCA) at UCA, the Caddo Conference Organization, the Arkansas Archeological Survey, and the Arkansas Archeological Society.

The conference began Friday, March 21st at 9 am with several research presentations throughout the day. Twelve presentations and three research posters were presented. Additionally, several book publishers and Caddo artists displayed books and art for sale.

There were 45 paid registrants attending the conference. Maximum attendance was during the Saturday afternoon public session, which is estimated around 100 people.

A special Saturday afternoon "Caddo Art and Heritage" session featured Caddo culture, art, and dance. In the session, six contemporary Caddo artists discussed their ceramic, beadwork, and stonework art.

\section{ABSTRACTS for the 61st CADDO CONFERENCE}

Drexler, Carl G. (Arkansas Archeological Survey), and Fiona M. Taylor (Arkansas Archeological Survey)

Lost in the Little River Region: Preliminary Notes on Lockesburg Mounds

Nestled between the Great Bend and Middle Ouachita regions of southwest Arkansas, the Little River Region has received comparatively little attention from archeologists. With no summary of its archeological significance published in the past forty-eight years, it comes as no surprise that our understanding of the area is partial, at best. This paper seeks to address that shortfall by presenting some background on a site that has been largely overlooked by archeologists, and which stands to substantially alter how we understand the Caddo presence in the Little River Region. It also adds a dimension to the early history of Caddo Archaeology.

\section{Earles, A. Wayne Tay Sha (Caddo Nation of Oklahoma) \\ Caddo and Spiro Lithics: Cultural and Contemporary Art}

This presentation will begin with some background information, discuss information on my methods and materials, and explain my own inspirations and my hopes for Caddo youth to continue our art. I will be discussing several pieces of art that are currently in the Stephen F. Austin State University/Cole Art Center exhibit, "Caddo Contemporary: Present and Relevant" in Nacogdoches, TX. I will also be discussing several other artworks including both cultural stone art and contemporary stone jewelry with engraved traditional ancient Caddo/Spiro designs.

\section{Early, Ann M. (Arkansas Archeological Survey) Caddo Pottery Away from Home?: A First look at Caddo Vessels in the Whole Vessel Inventory from NMAI, Gilcrease and the $\mathrm{U}$ of A Museum assembled for the Carden Bottoms Project}

One task for the Carden Bottoms Research Project undertaken by the Archeological Survey and Indian Nation partners was to photograph and document Carden Bottoms region pottery in three main repositories, the National Museum of the American Indian, the Gilcrease Museum, and the University of Arkansas Museum. Graduate Student Leslie Walker used some of the information for her dissertation, and the database will play in integral part in the full analysis of artifacts recovered during excavation of several houses at the 
Carden Bottoms site between 2011 and 2012. I will use the database to compare the range and distribution of Caddo vessels in the whole vessel assemblage and in the domestic features. This is a preliminary look at the actual types of Caddo vessels in the heritage collection.

\section{Renee Erickson (Center for Environmental Management of Military Lands)}

An Archaeological Study of the Earspools of the Arkansas River Valley and Surrounding Regions

Archaeologists and collectors have recovered earspools from sites throughout the Arkansas River Valley and surrounding regions. These items vary in form, material type, and decorative motifs. In this paper, I discuss how the differences in the distribution and variability of earspool attributes correspond to the archaeologically defined northern and southern Caddo regions. I identify what chronological variation is present in the earspools and if certain earspool types are diagnostic of Spiro cultural phases. I also examine what the degree of diversity and standardization of earspools with decorative elements indicates about the nature of these items of personal adornment.

\section{Earles, Chad Nish (Caddo Nation of Oklahoma) Contemporary Caddo Art}

Chad "Nish" Earles, visual artist and graphic designer, was born and raised in Oklahoma City and is a member of the Caddo Nation of Oklahoma. Chad enjoys creating artwork in various mediums such as drawing, painting, screen-printing and digital art. After receiving his BFA in Graphic Design from Atlanta College of Art in Georgia, Chad began his career in art and design at award winning design firm Critt Graham + Associates. Working his way up to Senior Designer/Art Director and Web Designer, Chad created a wide variety of projects for nationwide clientele including: Aéropostale, ANN INC. (Ann Taylor and LOFT), The Coca-Cola Company, Kodak, Philips and Wendy's. In 2011, Chad founded Nishology, his signature art and design brand with a mission to perpetuate Caddo art, culture and traditions. Based in his hometown of $\mathrm{OKC}$, Chad is currently participating and exhibiting his artwork at numerous art markets, festivals, museums and cultural events in Oklahoma, New Mexico, Texas, Arkansas and Louisiana.

\section{Earles, Chase Kahwinhut Earles (Caddo Nation of Oklahoma)}

Traditional Caddo Pottery

I create my tribe's traditional pottery to help educate and carry on the culture of my people. The once grand and widespread tradition of my people's Caddo pottery has now been reduced to a shadow of its former self and almost even disappeared completely. With the help of the only living Caddo pottery revivalist, I got started down the path of my artistic expression of our tribe's traditional pottery to help current and future generations understand the beauty and craftsmanship and uniqueness of our ancient pottery methods and culture. I will be talking about how I got started creating Caddo pottery and what inspired me. I will discuss how I create my work from hand dug clay and pit firing and the challenges of presenting Caddo pottery to the Native American Art world.

\section{Ford, Paige (University of Oklahoma)}

New Approaches to Unanswered Questions: Neosho Phase (AD 1400-1650) Pilot Study Results

The Neosho culture (AD 1400-1650) in northeastern Oklahoma is widely discussed in archaeological literature beginning with Baerreis' (1940, 1941) definition of it as a distinct focus. However, in tracing the intellectual history of research concerning Neosho, it is clear that researchers have struggled in its definition and in clarifying its relationship to preceding and surrounding cultures. In particular, archaeologists have been primarily concerned with questions of origins (where Neosho people came from) and cultural affiliation. Researchers have relied upon similarities in material culture trait lists to argue for Neosho comprising a group of migratory Plains agriculturalists or indigenous descendants of Caddoan-Mississippian peoples in the Arkansas River Valley. Such methods have proven insufficient, and Neosho-related research has been stuck with these unanswered questions. Using social network analyses on ceramic attribute data derived from Neosho and nearby Fort Coffee (AD 
1450-1600) sites in Oklahoma, the research presented will demonstrate new approaches that serve to sidestep those unanswered questions and focus instead on the relationships between Neosho peoples and their neighbors during the Late Pre-Contact period.

\section{Halfmoon, Raven (Caddo Nation of Oklahoma)}

Raven Halfmoon Artwork

Raven Halfmoon is from Norman, Oklahoma. She attended the University of Arkansas where she earned a double Bachelors Degree in ceramics/painting and cultural anthropology. Her work has been featured in multiple exhibitions throughout the US as well as internationally. In 2017, Raven completed a longterm residency at the Red Lodge Clay Center in Red Lodge, Montana. Raven is currently based in Norman, Oklahoma where she is working to establish her own studio and continues to produce work at the University of Oklahoma. She is represented by Gallery FRITZ in Santa Fe, New Mexico. In this presentation she will be discussing what inspires her and how she creates her work and the challenges she faces in the field of fine art today.

\section{Hammerstedt, Scott W. (Oklahoma Archeological Survey) \\ Ongoing Fieldwork at the Andrews Site, Sequoyah \\ County, Oklahoma}

Since the spring of 2018, Oklahoma Anthropological Society volunteers under my supervision have participated in excavations at the Andrews (34SQ521) in Sequoyah County, Oklahoma. The original surface collections conducted at the site by Society member Mel Phillips as part of his Little Skin Bayou survey suggested that it dated to the Archaic. Subsequently, we conducted geophysical survey and five days of excavations; the results of which indicate that the site may also have a Spiroan component. I discuss preliminary data produced by our remote sensing and limited excavations, and outline our plans for future work in May 2019.

\section{Hawkins, Yonavea (Caddo Nation of Oklahoma)}

Bead Work and Caddo - How it came to be...

Though she has a degree in Fine Arts and an advertising/ printing back ground as a graphic designer and print buyer, Yonavea started beading cultural items and sewing for herself and family. When asked to participate in her first art market she entered her own pair of Delaware moccasins in the Bead work category at Red Earth. She has since continued to compete in other juried Native American art market competitions with moccasins, beaded cultural items and loomed beaded belts in the Bead work or Cultural categories.

\section{Hazeslip, Lindsey (University of Central Arkansas), Robert Mauldin (University of Central Arkansas), and Duncan P. McKinnon (University of Central Arkansas) \\ Classification of Caddo Pottery Sherds using SEM-EDS}

The purpose of this project is to classify temper from different types of Caddo pottery sherds and determine sub-categories that exist, if any. This project also analyzed red pigment from the surface of Caddo pottery sherds to determine the composition. The pottery sherds are from the Bowman site (ca. A.D. 1100-1500) located on the Red River in southwestern Arkansas and were initially classified based on physical appearance using a light microscope. The sherds were initially divided into categories based on dominant temper: bone, clay, shell and grog. Early Caddo potters used only clay (or a lack of temper), whereas later production included the addition of bone, shell, or grog (ground, previously fired clay). The next step in the project used a scanning electron microscope with an energy dispersive x-ray spectrometer (SEM-EDS) to analyze the pottery sherds in an attempt to verify or modify previous physical classifications. SEM-EDS data indicated the bone-tempered pottery samples contained additional phosphorus and calcium, while the shell-tempered samples contained only additional calcium. SEM-EDS analysis of the red pigment indicated it was red ochre (ferric oxide or iron (III) oxide). 
House, John H. (Arkansas Archeological Survey)

Ceramic Variation at Kuykendall Brake

Excavations at the Kuykendall Brake site in Pulaski County, Arkansas in the 1990s exposed remains of a burned late prehistoric/protohistoric structure and accompanying burial feature beneath a small mound. Cultural material left on the structure floor at the time of the structure's destruction by fire include deposits of burned grain and other botanical materials, ground lithic artifacts, and 34 whole or fragmentary pottery vessels. The vessels include jars, bowls, and bottles exhibiting a variety of shapes, decorative treatments, and designs. This group of vessels existed in a single cultural context at a single point time. Results from detailed study of formal variation in this group of vessels may further interpretation of vessels assemblages from other archaeological site contexts in the region and beyond.

\section{Lockhart, Jami J. (Arkansas Archeological Survey) Updating Maps for Caddo Sites in Arkansas}

This presentation will describe an integrated technological methodology being used to supplement archeological maps in our digital site files. Drawing upon information for a number of Caddo sites in Arkansas, enhanced digital methods are used to discover, locate, interpret, and precisely map archeological features in the State.

Middlebrook, Tom (Texas Archeological Stewardship Network), and Colleen Hanratty (University of Texas at Tyler)

A Pilot Study in the Use of pXRF Analysis of Caddo Ceramics

$\mathrm{X}$-Ray Fluorescence analysis has been used in archeology for over fifty years yet there may be no published reports of its use in Caddo ceramic studies based on a review of a recent comprehensive Caddo bibliography. This pilot study employed $\mathrm{pXRF}$ data to assess elemental composition of 12 ceramic objects excavated from a shaft tomb in Shelby County, Texas (41SY27) in 2000 by THC archeologists and Stewards. One vessel, a Hume Engraved bottle, appeared to have been a trade item from the Upper Neches Frankston phase some seventy-five miles distant. This vessel yielded pXRF count values that marginally differed from the range of the other ceramic objects when using iron, calcium, potassium, chromium and arsenic comparisons. Limitations and future opportunities with $\mathrm{pXRF}$ will be discussed.

\section{Middlebrook, Tom (Texas Archeological Stewardship Network)}

The Westerman Mound (41HO15)

George Kegley of THC's Building Commission Survey recorded a 20m X 25m mound on the Grover Westerman place southeast of Kennard, Texas in August 1969. Subsequently Dee Ann Story visited the site in 1970 and 1986 making additional surface collections in the 10 to 15 acre village area around the mound. Tim Perttula's (2015) review of recovered artifacts suggest that the mound may relate to an Early Caddo occupation of similar age as the ones at George C. Davis site 18 miles to the north. Radiocarbon dating of a charred corncob had a median calibrated age of A.D. 1242. A number of sandy paste sherds at the site led Story to speculate that the origins of the site may lie in the Woodland period. This paper will report on recent visits to the site and future plans for limited investigation.

\section{McKinnon, Duncan P. (University of Central Arkansas) \\ Caddo Ceramic Database: An Update}

Over the past several years, I have been synthesizing, with the help of numerous Caddo archaeological researchers, a comprehensive multi-state material culture database to evaluate interregional interaction and community. The database is primarily composed of whole Caddo vessels documented from published excavation summaries, archaeological reports or grey literature, and various photographs taken of private collections. This presentation will provide an update on recent case studies as the database continues to grow. 
Mulvihill, Tim, (Arkansas Archeological Survey) George Sabo III (Arkansas Archeological Survey), Jami J. Lockhart (Arkansas Archeological Survey), Jessica Crawford (Arkansas Archeological Survey), and Larry Porter (Arkansas Archeological Survey) The Preservation of Cavanaugh Mound 3SB3.

Located within the city limits of Fort Smith, Arkansas, Cavanaugh Mound is a late prehistoric platform mound. No formal excavations have ever taken place, but in the past tunnels were dug into the eastern and southern sides of the mound with no reported artifacts. During the 1960s, a large section of the eastern side was removed, causing severe erosion over the years. In 2005, the Archaeological Conservancy acquired the mound and in 2011 the Arkansas Archeological Survey conducted a limited geophysical survey. In 2017, the Conservancy financed the reconstruction of the eastern side to prevent further erosion and the Survey was able to record portions of the east profile of the mound.

\section{Redcorn, Jeri (Caddo Nation of Oklahoma)}

What's in a Name? Call it Caddo.

Jeri Redcorn is recognized internationally for reviving the Caddo pottery-making tradition. First Lady Michelle Obama selected Redcorn's "Intertwining Scrolls" pot for display in the Oval Office. The artwork is a traditional Caddo design from more than 300 years ago. The Smithsonian, the Oklahoma Museum of History, Spiro Mounds, and the Bob Bullock Texas State History Museum permanently display her work. Redcorn's honors include Artist in Residence at the Art Institute of Chicago, where she was featured in the video, "Hero, Hawk and Open Hand;" Rockefeller Fellow, Chicago Newberry Library; and John Hay Whitney Fellow, University of Oklahoma. The University of Texas and the University of Oklahoma have included her story on their websites. Redcorn has lectured at the Smithsonian, the Art Institute of Chicago, Yale University, Illinois University, and the White House Institute of Museum and Library Services conference. Her story was shown in "Arkansas's FIRST PEOPLE" on AETN, Arkansas. The documentary is the companion series to WGBH/ PBS, "We Shall Remain.” In this presentation Jeri will be addressing the reasons to change Caddo Pottery Type
Names to more culturally relevant designations for the Caddo people. This need reflects policies contributing to Caddo loss of homeland, language and culture. Moving forward to bring Caddo history to the present, by the Caddo, for the Caddo of what is important to Caddo Nation.

\section{Sabo III, George (Arkansas Archeological Survey)}

The Archeology of Storytelling at the Spiro Ceremonial Center

Storytelling is a powerful instrument for teaching, learning, and creating new knowledge and information among communities around the world, including Native Americans past and present. Storytelling is primarily a dramatic performance that does not often yield a diagnostic material signature; to what extent, then, might such performances be reflected in the archeological record? This presentation explores links between narrative traditions and artistic representation, and reviews recent research and a new digital project about early 15 th century storytelling performances at the Spiro Ceremonial Center.

Selden Jr., Robert Z. (Center for Regional Heritage Research, Stephen F. Austin State University) Ceramic Morphological Organization: Quiddity of Shape for Hickory Engraved Bottles

This study expands upon a previous analysis of the Clarence H. Webb collection, which resulted in the identification of two Caddo bottle shapes used in the manufacture of Hickory Engraved (HE) bottles. The current sample of Caddo bottles adduces threedimensional meshes from the HE specimens in the Webb collection, as well as 14 new meshes from six sites and one collection; all of which fall under the purview of the Native American Graves Protection and Repatriation Act (NAGPRA). Results confirm that HE bottle shape differs significantly by site in some cases, that the two discrete shapes identified in the previous study persist in this larger sample, and that morphological integration is not significant, meaning that those traits used to characterize bottle shape (rim, neck, body, and base) were not found to vary in a coordinated manner. Thus, while results confirm site-specific differences in shape 
and the manufacture of two discrete bottle shapes from two different (north-south) geographies, results do not support the hypothesis that Caddo potters adhered to a template of vessel shape associated with specific decorative motifs for this sample of HE bottles.

Selden Jr., Robert Z. (Center for Regional Heritage Research, Stephen F. Austin State University), John E. Dockall (Prewitt and Associates, Inc.), and Harry J. Shafer (Texas A\&M University)

Lithic Morphological Organization: Gahagan Bifaces from Texas and Louisiana

This study is focused upon an analysis of Gahagan biface morphology and enlists the three largest samples of these bifaces, to include that of the type site (Gahagan Mound) as well as the Mounds Plantation and George C. Davis sites. Results indicate a significant difference in Gahagan biface morphology at the Mounds Plantation site when compared with Gahagan bifaces from the Gahagan Mound and George C. Davis sites. A test of morphological integration indicates that the bifaces are significantly integrated, meaning that those traits used to characterize their shape (blade and base) vary in a coordinated manner. Tests for allometry and asymmetry were not significant. Results confirm that Gahagan biface production at Mounds Plantation differs significantly when compared with industries at Gahagan Mound and George C. Davis. Results augment previous inquiries, and provide additional evidence for a north-south divide based upon the morphology associated with communities of practice for Gahagan bifaces. When viewed in concert with similar shifts in Hickory Fine Engraved and Smithport Plain bottle morphology, multiple lines of evidence lend support to an increasingly robust argument for two previously unrecognized and morphologically-unique Caddo communities of practice.

\section{Swift, Catherine (Fairfield Bay Community Education Center)}

Myths and Misconceptions of the Edgemont Shelter

The Edgemont Shelter is part of the City of Fairfield Bay's Heritage Center and is identified by the trinomial 3VB06 on the National Register of Historic Places.
Commonly known as Indian Rock Cave it contains 11 carved petroglyphs on the Arkansas Archeological Survey's rock art database. Archaeologists have been visiting since the late 1800's and believe the cave was used as a place of celebration and shelter for five tribes, including the Caddo. There are stories about these images and their connection to this revered site, some are true and some are legend.

\section{Tahlate, Alaina (Caddo Nation of Oklahoma) \\ Caddo Language}

I will present a selection of stories from The Caddo Language: A Grammar, Texts, and Dictionary Based on Materials Collected by the Author in Oklahoma Between 1960 and 1970 by the late Dr. Wallace Chafe. There will be a discussion of Hasinai cultural values and worldviews encoded within the language of the texts.

Taylor, Fiona M. (Arkansas Archeological Survey), and Carl G. Drexler (Arkansas Archeological Survey)

An Update on the Holman Springs Site: Past, Present, and Future Research

Excavated in the 1980s by the Arkansas Archeological Society, the Holman Springs is a massive Caddo site and one of a few salt-processing sites in Southern Arkansas. This large collection of archeological material wasn't re-opened until 2015 when the SAU Research Station began a re-boxing initiative. That endeavor eventually led to me beginning a systematic ceramic inventory in 2017, research I am still conducting today. This paper will include an update on my current research, a report on the recent radiocarbon and botanical analyses, as well as our plans to wrap up this site at the 2019 Arkansas Archeological Society Training Program in June.

Trubitt, Mary Beth (Arkansas Archeological Survey), Chelsea Cinotto (Arkansas Archeological Survey), and Rae'Shawn Jones (Henderson State University) Update on the Hodges Collection of Native American Artifacts at Henderson State University

The Joint Educational Consortium (JEC), made up of Henderson State and Ouachita Baptist universities in 
Arkadelphia, Arkansas, acquired the Hodges Collection of Native American artifacts in 1977. Most of the items were collected from archeological sites in the Middle Ouachita River valley by Thomas and Charlotte Hodges in the 1930s and 1940s. The Arkansas Archeological Survey's Henderson State University research station staff curates the collection, and we have inventoried, photographed, and documented objects, published research articles, and created educational exhibits from this large collection. In 2017, human remains and associated funerary objects were transferred from the JEC to the Arkansas Archeological Survey's Fayetteville office for a NAGPRA inventory. Work continues on identifying unassociated funerary objects based on archival records. This year, we are moving the Hodges Collection from closed curation to open storage in the renovated Caddo Center on the Henderson State University campus to make it more accessible to students and faculty, residents of the local area, Caddo Indians, and other visitors.

\section{Williams, Jeffrey M. (Friends of Caddo Mounds State Historic Site), and Victor Galan (Friends of Caddo Mounds State Historic Site)}

Koo-Hoot Kiwat: The Caddo Grass House

The traditional Caddo Grass House built in 2016 at Caddo Mounds State Historic Site near Alto, Texas was the subject of a 30-minute PBS special that documented construction from the identification and collection of raw materials through the final thatching. Following the viewing of the documentary, we will describe damage to the structure expressed as a noticeable lean that progressed over the fall of 2018 and the emergency repairs to the structure that were made in the winter of 2018-19. The repairs have distinct features that may be expressed in the archaeological record. This information can be used to aid in interpretation of circular house patterns found throughout traditional Caddo lands.

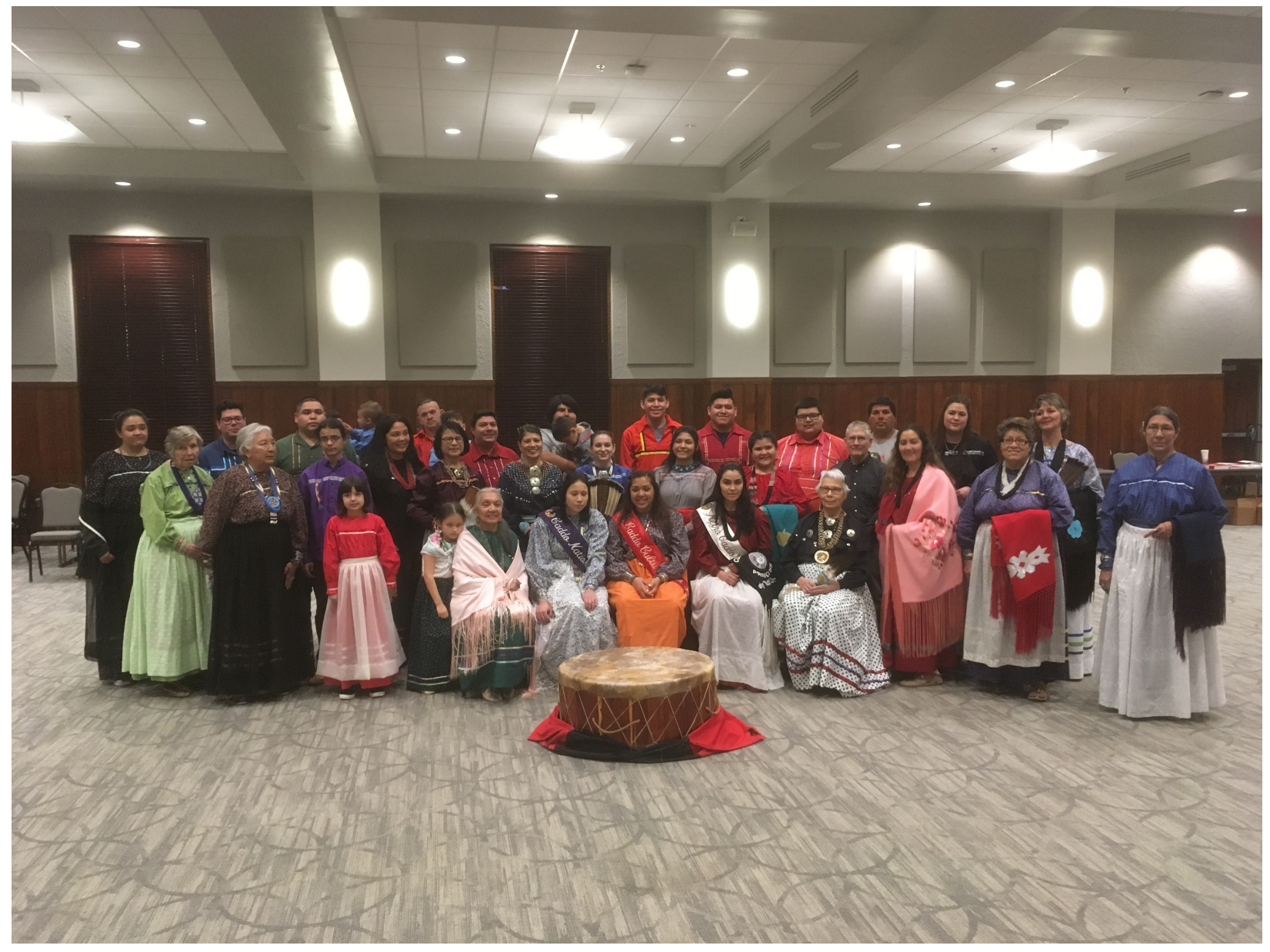

